\title{
CAN THERE BE A FEMINIST AESTHETIC?
}

\author{
Claire Raymond
}

\begin{abstract}
"Can there be a feminist aesthetic?" analyzes the difficulty of finding an ontological position from which to write about photography created by women. It interrogates the discomfort of inhabiting, socially, and in art and literature, the position of the embodied feminine, and seeks through aesthetic analysis to mine this discomfort. The essay argues that despite the social and intellectual discomfort of articulating a space of the feminine, in that this space is always already coded as oppressed, there is a value in interpreting photography created by women through the lens of feminist resistance. The article concedes that defining the word woman is always a risk, in that the term reflects manifold and contradictory embodied experiences. And yet, within this avowed risk emerges the only space of possible resistance to oppression, the opportunity to create a rearrangement of the visible so that the category of the oppressed woman, however phantasmatic, is re-envisioned as sovereign. However, each act of re-envisioning woman must be culturally specific. Hence, the essay concludes with an interpretation of Ethiopian photographer Aida Muluneh's series of images Dinkinesh (or, "you are beautiful"), evoking the remains of an Ethiopian hominid that were long considered to be the oldest of human ancestors. Muluneh reclaims this distant ancestor as Ethiopian, dressing her in an extravagant red gown, using photography to re-envision Dinkinesh's fall into history, granting this ancestor the power to haunt modernity.
\end{abstract}

KeYwORDS

Feminism; aesthetic theory; photography; Aida Muluneh; Walter Benjamin; Dinkinesh; haunting; women photographers

\begin{abstract}
RESUMO
"Pode haver uma estética feminista?" analisa a dificuldade em encontrar uma posição ontológica a partir da qual se escreva sobre as fotografias criadas por mulheres. Interroga-se acerca do desconforto de habitar, socialmente e na arte e na literatura, a posição do feminino corporizado e procura minar este desconforto através da análise estética. O ensaio argumenta que, apesar do desconforto social e intelectual de articular um espaço do feminino, na medida em que este espaço já é sempre codificado como um espaço de opressão, existe valor na interpretação da fotografia criada por mulheres através da lente da resistência feminista. $O$ artigo reconhece que definir a palavra mulher é sempre arriscado, na medida em que este termo reflete variadas e contraditórias experiências corporizadas. E, no entanto, dentro deste risco reconhecido, emerge o único espaço de resistência possível à opressão, a oportunidade de criar um reordenamento do visível, para que a categoria da mulher oprimida, por muito irreal que seja, passe a ser refocalizada como soberana. Contudo, cada ato de refocagem da mulher deve ser culturalmente específico. Por isso, o ensaio termina com uma interpretação da série de imagens da fotógrafa etíope Aida Muluneh, intitulada Dinkinesh (ou "és bela"), recordando os restos de uma hominídea etíope que são há muito considerados como o mais antigo antepassado humano. Muluneh reivindica como etíope esta antepassada distante, vestindo-a com um extravagante vestido vermelho, usando a fotografia para refocalizar a entrada de Dinkinesh na história, concedendo a esta antepassada o poder de assombrar a modernidade.
\end{abstract}

\section{Palavras-Chave}

Feminismo; teoria estética; fotografia; Aida Muluneh; Walter Benjamin; Dinkinesh; assombro; mulheres fotógrafas 
In October 2016, I completed a book, called Women Photographers and Feminist Aesthetics, and sent in the manuscript to the publisher. The process of writing the book, in particular the process of interacting with many of the photographers, and their estates, intensified my awareness of how fraught and contested are the cultural places of feminism. Can there really be a feminist aesthetic? What is the political force of photographic images, such that some images can rightly be called feminist? I take as my definition of feminist a force of political action - feminist does not signify an idea that pertains to an individual's feelings about herself, but instead to have any meaning at all, feminist must indicate a force toward political engagement. Feminist aesthetics indicates a political act in image. The book, Women Photographers and Feminist Aesthetics, hence, is a work of theory and analysis. But the practical struggle with this question of a feminist aesthetic took on a far less theoretical bent as I reached those chapters contending with living artists, or artists with living heirs, and began asking for reprint permissions. This paper, then, is a kind of nachtraglichkeit, a looking back with new insight at the premise of the book written. Some - certainly not all - of the living photographers discussed in the book brought forward questions contending with the words woman and feminist in the title, reflecting the important way in which womanhood emphatically is no universal bond, and issues of intellectual colonization, and colonization as such, haunt gender.

The fissures within the social and semiotic spaces of these concepts and terms, feminism and woman, the fault lines across national, cultural, racial and ethnic frames that contain these meanings, were known to me before launching this book, and yet, from interacting with the artists discussed in the book I learned about feminism in ways that are uneasily theorized. The connections, if such there are, between women have a paradoxical scorched earth and ineffable quality - visceral, felt, unreal, disavowed. And indeed, judging from the various responses I got when requesting image permissions for the book, individual photographer's connections with these words, woman, feminist, are sometimes weighted with ambivalence, and shame, and fear. Who wants to be called a woman? Not Judith Butler.

This venture into writing about the politics and aesthetics of feminism came to me also through my own ambivalent place in the matrix of gender. Having accepted a nontenure track teaching job, after a six-year gap during which I was a stay-at-home full time mother, I have struggled to stay afloat in the academy. Eight years ago, at a university in the south-eastern United States, I started teaching a course on women photographers because the then-chair of the Women Studies program thought it might be popular (she needed bigger numbers of students in her program's classes, to retain university funding for her program). The Women's Studies program chair thought that, with my work on the American photographer Francesca Woodman, I had a basis from which to teach. But for me Francesca Woodman was interesting not because she was female but because she was a photographer, a creator of extraordinary images. Thus, without an initially deep interest in the topic, I found myself teaching what indeed became a popular course on women photographers.

Semester after semester, students, mostly cis-women, filled this class, and their enthusiasm for the class was unlike the response I have gotten to any other class, including 
straight-up feminist theory. The class on women photographers gave the young women students female heroes, in the persons of women photographers - figures who Houdini-like did something strange and magical with the camera, burned the male gaze off themselves, creating image worlds that objected to and resisted oppression. By creating visual objects (the photograph is always an object, though uncannily it also repeats the visual representations of other objects) these photographers shaped an alternate sphere in which, despite difficult lived circumstances, the woman photographer made a vision of resistance, deploying vision as resistance.

Photographer Vivian Maier (1926-2009) epitomizes this sleight of hand. Born to French immigrant parents, Maier lived in American in the mid $20^{\text {th }}$ century working as a nanny, caring for other people's children all her life, all the while taking thousands of photographs with her viewfinder camera (Maloof \& Dyer, 2011). She went entirely unrecognized as a photographer during her lifetime. Her photographs were found in a storage shelter after her death and how they came to be publicly circulated is complicated story, in which men who purchased Maier's in arrears storage shelter unintentionally purchased her photographs and then circulated them (Maloof, 2014, pp.19-36). Notwithstanding her complete lack of a role in the circulation of her photographs, Maier's images insist, obsessively, on this woman's vision: what she sees, that she sees. In her photographs, Vivian Maier is no one's servant, though in her life she always was. This shelter (the shelter of the photographs-as-images, and the storage shelter where the photographs-as-objects were stored) where vision becomes image-object was such a physically small thing: Maier's photographs were mostly not printed during her lifetime, but discovered as undeveloped film after her death. But this slight physical substance, of undeveloped rolls of film, expanded to show Maier's singular vision of urban mid-20 $\mathrm{O}^{\text {th }}$-century America.

There is certainly more that can be said about the gendered conditions and precariousness of Maier's posthumous success story, but the point I want to make here is how the terms of her subversion of disempowerment were, generally, not the stopping point for students enrolled in my "Women Photographers and Feminist Aesthetics" classes. The reality of her life - that Maier never stopped being a nanny until she became elderly at which point, in classic capitalist narrative, discarded as a worker she became indigent, was not the stopping point for the students. Instead, what appealed to them was the effect of Maier's photographic subversions: that even though she lived her life oppressed by gender and class circumstances, in her photography she refused that subjugation, and in the uncanny embodiment of photography, her refusal of subjugation forms an entire image-world.

The photographic image is the place where a feminist aesthetic occurs or does not occur: the photographer's lived life is not necessarily apparent or even meaningful in this paradigm. Thus freed from primarily engaging the pain of what happens in women photographer's actual lives, my classroom of "Women Photographers and Feminist Aesthetics" buzzed with unusual energy: each photographer studied became a model of someone who envisioned a place where gendered oppression was overcome in the rhetoric of photographic image. The college women taking the class faced issues college women 
face: body-image issues, non-consensual sex issues, subtle cultural prohibitions against overachieving in school, or against achieving in male-dominated fields. But this course on photography never directly addressed any of that.

Instead, it obliquely said, look, Lee Miller (1907-1977) survived childhood rape and Man Ray's tutelage, and she still created this forceful oeuvre (Burke, 2007). Indeed, for the purposes of this class, Diane Arbus (1923-1971), and Francesca Woodman (19581981), could be said to have survived their own suicides; their work was the substance of the class, not their lives (Raymond, 2016; Arbus, 2003). And yet the magical lightness of feminist transformation through photographic image that we experienced in the classroom, in the context of a book based on the course gained the weight of the real. Putting into place the achievements and limitations of mortal artists, a much heavier task, on the page became a reckoning with the discomfort women - myself included - feel in presenting ourselves publicly - that is, before men - as women. Indeed, I knew, writing the book, that because it had the word woman in the title it would never be considered important, as a work of theory, in the way that a book that is not about women has the chance to be. Each time I have chosen to write about women, women poets, women photographers, it is with an increasing understanding that this activity places me in ghetto of sorts, that is, in a space as a scholar where it will be assumed that I have never written about anything serious.

The difficulty in leveraging feminism as a legitimate form of politics is deeply entwined with the difficulty of writing or claiming the word woman. The destructive history of being called feminine or its close cognate, feminist, verge closely to this social figure called a woman (Solnit, 2017, pp. 17-69). And yet, feminism and, hence, feminist theory, are entirely political entities, emerging from and effecting the polis. The risk of claiming a feminist aesthetic has not only to do with the culturally loaded (and demeaned) force of the word woman, but also with the problematic status of the concept of aesthetics and its relationship to politics. Indeed insofar as the ontology of gender is arguably hollow, that is, determined by one's external appearance and its situatedness, aesthetics and the politics of gender are deeply intertwined.

Looking at politics and aesthetics, I turn to Walter Benjamin's persuasive argument about the connection between fascism and aesthetics. In this connection is the nub of the risk of aestheticizing the political; and also the argument for the difference between aestheticizing the political and politicizing the aesthetic. The aesthetics of politics, Benjamin argues (in 1931), are most clearly expressed in fascism (Benjamin, 1968a; Benjamin, 1972). He contends that fascism works by depriving people of the chance for material betterment, or the chance to actively participate in political decisions, in tacit exchange for the sanctioned permission to express themselves, that is, to express and give credence to their anger at those whom they determine are not like themselves. Benjamin goes on to draw a connection between the permission granted by fascism for citizens to express their hatred of those whom they perceive to fall outside the rigid boundary of putative proper citizenry and the role of imagery in fascism, the most striking example of which would be Hitler's concept of an Aryan ideal. Benjamin is arguing here that a 
specific aesthetic takes over politics in fascism, the surface image covering meaning the face that fascism creates hides its sadistic actions (Hillach, Wikoff \& Zimmerman, 1979). But Benjamin does not stay with the conclusion that politics aestheticized are always fascist. Instead, he goes on to argue that photographic images can also be deployed to strengthen leftist resistance to fascism.

Benjamin's argument here turns on the idea of time, and its representation in photography. He suggests that only the quick, and violent, cutting off of the moment of vision that photography performs accurately captures the modern condition, with its violent and sudden turns. His description, in his Theses, of Paul Klee's Angelus Novus (which Benjamin dubs the "angel of history") pulls precisely on photographic description: in a flash all at once to see history is the only way to accurately see it (Benjamin, 1968b). Here, seeing photographically is implicitly posited as the vision that can allow one to transcend ideology. In earlier discussion of photography, Benjamin also argues that photography can be used as a tool to counter fascism because of photography's singular relationship to duration: a tool to show where things are broken and how their broken pieces could be fit back together. In fitting together different photographs (photomontage), photography could have its most substantial subversive or counter-culture force, contends Benjamin.

Jacques Rancière, in Aesthesis, argues that aesthetic form is the only real carrier of political change, that it is not the surface political content of an image that alters culture but instead what Rancière calls the "aestheton", or, the structural-cultural force of the image (Rancière, 2013). Here, Rancière moves away from a Clement Greenberg notion of the aesthetic as a grid, or pure form, and also turns from Benjamin's notion of concerted planned political art (think Barbara Kruger, Martha Rossler). Instead, he argues (in the spectral footsteps of Erwin Panofsky) that form carries symbolic content. In this way, political photography that rehashes borrowed content, critiquing it in that revision, also repeats in some muted way, the original inspiration for the very content it wishes to critique. Symbolic form that overturns or subverts oppressive ideology, then, has to be something new, an image not yet seen.

The aestheton - the structural and cultural force of an image - is an effect rather than strictly speaking an intention. It is possible that a photographer's intention could produce the effect she wants but not necessary. Immanuel Kant's theory of "purposive purposelessness" as the definitive force of the sublime here comes to mind. But the argument that Rancière forwards about the emergent and immersive quality of aesthetics as politics has as much to do with contemporary politics as Kantian theory. The image either transmits or disarticulates the force of contained social myth, as Diane Arbus eloquently suggests: "a photograph is a secret about a secret" (Lubow, 2016, p. 4). The photographic image tells what it tells by being seen, not by being shown. It works always within the idiom of social myth and yet also can contend with, object to, terms of its contemporary social imaginary through formal shifts in the image.

If feminist aesthetics can be photographic more so than other media, that is because of photography's privileged and troubled relationship to time. A photograph looks dated within the year of its creation, and ever more so as time moves past its frozen 
plane. Time is the hinge of the photograph, holding its formal qualities to the brunt, blunt fact of time, time's passage in a cultural and material sense, and also time is the door of the photograph, the opening through which thought or belief is revealed by its uncanny connection with the embodied, material real. Photography's visceral and uncanny tie to the physical passage of time makes it vulnerable and powerful politically: it is always of the moment, and also can (though rarely) surpass the moment by holding it still in an act of translative vision, that which crosses, which translates the material and social real into image, and changes the viewer.

The photographic duration and fragmentation of oppression means: a photograph can show or refuse the way of seeing that has become a form of domination. The photograph can be a countering object, as it exists materially, visually moving against material habit as a condition of understanding. The duration of the photograph is both instantaneous and enduring; its own hyper-real space, commenting on, commemorating, and shaping the lived material world, iteratively tied to it. Photography is a kind of circumflex inflecting ways of seeing, and as such is an obvious tool for politics.

\section{THE ANGEL OF HISTORY}

As discussed at the beginning of this essay, Benjamin's use of the term the "angel of history" describes with extraordinary eloquence the way that photography composes, and reflects, the fractured or existence of modern life (Benjamin, 1968b). In this sense, the essay reflects implicitly the political capacity of photography. Benjamin's theory of the optical unconscious supports his argument that photography is the medium best able to convey the modern reality of shock: a photograph can show us what is there that we usually edit out or look away from. This completeness, within the narrow world of the photographic image, makes a photograph uncanny in its revelation of layered aspects of catastrophic history. Unlike other art forms, the photograph is not remembered or distilled, but supplants the function of memory and distillation. Even as the photograph acts as an analog of memory, it displaces the interior discourse of memory and distillation and, in this skewing of time, functions like a déjà vu, or a trauma.

Benjamin's Theses on Philosophy of History in which he describes Paul Klee's Angelus Novus as an "angel of history" contends with the photographic (Benjamin, 1968b, p. 257). For, here, Benjamin argues that what we perceive as a chain of events, history, is really one event (a traumatic one, a catastrophe) (Benjamin, 1968b, p. 257). This metaphor is so deeply immersed in the visual that it conjures the photographic flash, that instant in which an image comes to stand as image. The quality of trauma that is very clear in his Theses on Philosophy indicates Benjamin's theory of the photograph as a traumatic visual apparatus or a technique in which trauma is constituent.

The trauma of photography is the abruptness and absoluteness with which it records the image of what happens. Not only is this manner of image making traumatic - that is, temporally abrupt - it also reflects the trauma of modernity, the way that things happen suddenly without our preparation for them (like car accidents, or, in Benjamin's reference, the rise of Nazism). But the photograph is also an image that can hold 
information about past-present-future in one form. The photograph then is at once a medium that imposes a traumatic gaze - a fractured, sudden, rapid-gaze - and also is capable of recording layered traumata. Photography as the medium of trauma is Benjamin's insight into the photograph's elliptical relationship with aura. The photographic image strips aura from all that is not photographic, in the process becoming itself stripped of aura (completeness, actual ontological meaning). And yet the photograph also can be endowed with aura in that it stands - in Benjamin's elliptical Theses on Philosophy - as the only way that the trauma of history can be seen: photographically, in a flash. Benjamin's claim that everything that "has been smashed" can only be made whole again if we turn and in an instant see the layers of history not as sequent but all at once, suggests not only a photographic mode of seeing but a collaged photographic mode of seeing (Benjamin, 1968b, p. 257).

The erosive force of photographs - that they remove from context every person, object, and event that they represent - is also what gives the photograph its traumatic aesthetic force. The camera as the angel of history can be turned to see what is smashed but cannot in itself save anything it sees, compelled as it is by the uses of progress. Photographs' quality of being torn from context reflect and represent the social structure of the modern world that is continually unpredictable, violent, and random. Feminist photography makes use of this traumatic capacity inherent in photography to expose, elliptically and lyrically, symbolically and formally, the trauma of sexist oppression in its varied specific historical contexts.

If we accept, with Benjamin, that photography is almost always political (even and indeed especially those images we think of as private and personal, it forwards a politics), in what ways can feminist photography diverge from fascist use of the image, images that are created to contain and control the imagination of the polis? In other words, one of the points that Benjamin makes most profoundly, and that is most troubling, about photography and politics, is the way that photography is a "natural" tool of fascism, and we must not ignore this capacity of photography to circulate images of oppression when we seek to elucidate how photography may also counter oppression. While earlier critics of a feminist aesthetic - Barbara Freeman and Rita Felski - objected to the idea that there could be a uniform feminist vision (basing their assumptions on the belief that such an aesthetics would assert a false ideology of unity among women), my concern is less with the spectre of a unary femininity and more with the spectral force of the photograph: its vulnerability to being used as propaganda (Freeman, 1997). How can a feminist aesthetic, in photography, be different from a fascist aesthetic, not just by opinion but formally, structurally? Can photography be radical or does it always replay the very cultural terms that permit its reading? What, then, is the relationship between gender and time, between feminist movement and time?

For this question, I turn to a photographer whose work, like her personal history, toggles between the dominant capitalist structures of the West, and the precarious and powerful intersection of ancient and new culture in contemporary sub-Saharan Africa. Photographer Aida Muluneh, born in Ethiopia, spent decades living in other countries 
- Yemen, England, Cyprus, Canada, the U.S. - and then worked as a photojournalist for the Washington Post, before deciding to return home to Addis Ababa. She took her maternal grandfather's last name, Muluneh, to signify her connection through her mother (who alone raised her) to Ethiopia. Once back in Ethiopia, Muluneh turned her photojournalist eye to the country for which she felt immense nostalgia and in which, she notes, "nostalgia is our national sport". Past/Forward (2009), the work resultant from Muluneh's initial re-encounter with Ethiopia, is documentary photography with a lyric edge, a searching and gorgeous work, but it is Muluneh's oeuvre since 2010 that I will suggest carries a clear feminist aesthetic?.

In these works - 99 Series, The Wolf You Feed, and The World is 9 - Muluneh creates avant garde photographs that, while photographic works, incorporate paint, set design, and costume, to form highly symbolic images of African women in settings that reference Ethiopian history, but obliquely, symbolically, and in Muluneh's own image vocabulary. These newer works often exclusively center on a woman, a female model. The models are women that Muluneh chooses because, she says, just as she does, so also they carry visually the symbolic of Ethiopia on their bodies: that is, others who see them interpret them as African women. Her photographs, then, take on the history of photographic representations of African women as demeaned, starved, and dehumanized and subverts this imagery not by presenting realistic counter-images but instead by creating a symbolic visual landscape that presses the viewer to interpret the African women pictured on terms shaped by Muluneh's photograph, rather than oppressive Western and masculinist terms.

The photographs comprising the 2014 series, The Wolf You Feed, focus primarily on a young African woman covered in thick body paint. In the heavily applied paint, Muluneh derealizes race: the woman's skin is so thickly coated with paint, nothing natural can be inferred regarding skin's appearance. This emblematic use of paint is Muluneh's cue that her photographs are not to be interpreted as images about racial difference but instead they object to the construction of race, and to colonialist ideology and, in their objection, contend with its history. As she notes: "photographs can create or distort reality". A close up of the young model's face brings us eye to eye with her (Figure 1). Muluneh positions the image so that we face the woman (Muluneh, 2009).

As philosopher Emmanuel Levinas argues, "facing" is the ethical stance in which we take on the position of the other person whom we face: looking eye to eye we are pulled into a moral contract with the person whom we face (Hand, 2011). Muluneh's model faces us with her skin painted blue and bisected by black dots (an allusion to Xhosa painting of adolescent boys during the transition to manhood) (Jayawardane, 2016) ${ }^{2}$. Hands painted black and dark red, also bisected with dots, hold the model's face: she is caught in history but she is clear-sighted. These denaturalized photographs strip away conceits of photographic veracity, what Baudrillard called the diabolical capacity to substitute the fake for the real (Baudrillard, 1994). Instead, Muluneh's photographs emphasize their

\footnotetext{
' Aida Muluneh Past/Forward: Photography in Ethiopia, Colby College Art Department Lecture, Waterville, Maine, April $23^{\text {rd }}$, 2015.

${ }^{2}$ Aida Muluneh, Personal communication to author, August, 2016.
} 
own elaborate staging, inverting the diabolical substitutions of photojournalist images of African suffering, images (such as Anthony Suau's, Sebastio Salgado's and James Nachtwey's) that present African identity as entirely corporeal and brutalized. In contrast to invasive images of Western photojournalism, Muluneh opens an eidetic and oneiric space of symbolic possibility.

Her series of photographs reenacting the steps and fall of Lucy, (referring to the skeletal remains of an early hominid discovered in Ethiopia and long believed, by anthropologists, to be the oldest skeleton of a human being), reverse the scientific Western male gaze and instead assert a brilliantly powerful woman who, in Muluneh's imagery, is mythical, standing or falling in her own world, not to be taken for others' use (Figures 2 and 3) (Kimbel \& Delezene, 2009). Why photography for these highly symbolic image landscapes that are anything but snapshots? Because photography with its conceit of the natural and the realistic provides precisely the tension that Muluneh needs to overturn oppressive ways of seeing. The realist conceit that is intrinsic to photography, Muluneh draws from, subverts, and plays out through highly orchestrated images that resist becoming the hyper-real, that is, resist exchanging the real that can be seen for the ideology that is shown. Her photographs work against ideology, and refuse to model the African woman as a terrain for the imposition of others' symbols. Instead, Muluneh reinvests this figure with potency that is both grounded in African history and also enigmatically personal, fusing Xhosa face painting patterns with Ethiopian Orthodox framings of icon paintings (Jayawardane, 2016)3.

Refuting an archaeological and anthropological stereotype - Lucy, the Ethiopian woman as "mother" to all humans - Muluneh presents Lucy as a terrifying and enigmatic presence, hovering over all that becomes human, supervising what she sees rather than becoming an object of scientific regard. As Michel Foucault makes clear in the Birth of the Clinic, the scientific gaze is one of mastery, mastering by scrutiny and, far from being objective, its drive for power and domination is so utterly masked that it perverts the idea of objectivity (Foucault, 1994). In her photography Muluneh reclaims Dinkenesh, or Lucy, superseding the scientific gaze.

The haunting and painful force of Muluneh's photography played out in my writing of the chapter on her work. I had to re-face the feminist problem of the inadmissibility of the knowledge of being a woman: because this knowledge has no core - a feminist aesthetic is always a visual response to a very specific set of cultural circumstances and history. Being a white woman, an American, I can speak about and speak to the issues facing African women but I cannot speak from the place of those issues. Instead, the images that Muluneh creates speak from that place, and the job of my writing was, and is, to encounter the new clarity of her vision. A feminist aesthetic, then is typified by force that cannot be predicted. Its distance from fascistic representation as politics is here: the desire of the fascist is always knowable beforehand. But the desire of the woman artist who wants us to see anew, to rearrange the visible (as Rancière argues in the Emancipated Spectator) is knowable only after the work is granted to audience, that is, people both familiar with and foreign to the artist's place of origin, in the fullest sense (Rancière, 2009).

${ }_{3}^{3}$ Comments regarding Xhosa face-painting, Aida Muluneh, Personal communication to the author, August, 2016. 
In the interaction with audience - the act of perception - the aesthetic event occurs. By this I do not necessarily invoke Barthes' theory of the death of the author, leveraging the readerly text for photography, the seen event, instead I mean that the force of the aesthetic that carries and is motivated by traces of history and culture (without which it has no meaning) is feminist in response to and in creation of culturally specific image vocabularies that reveal oppressive ways of seeing and offer a kind of delayed catharsis, shedding the old, replacing it with an edge of the violent (Barthes, 1977). The voluminous red garments - dress and cloak - of Dinkenesh, in Muluneh's 2016 photographs, suggesting blood with all its extensive and culturally indeterminate meanings, turn back the Eurocentric clinical gaze, honoring an African woman who fell into history, retrieving and renaming her in Amharic: her name that means you are beautiful.

Barthes' idea of the punctum - the painful aesthetic force of individual photographs - was written, I suggest, partly in response and rebuttal to the Family of Man, that is, as refusal of the ideology by which photography was put forward as a "universal language" (Barthes, 1972). Barthes' punctum declares that it is never so. The punctum - the shot arrow - of a photograph with a feminist aesthetic is this moment, painful and pleasurable, of undoing what we once oppressively were shown so that we can now see anew. The language of Muluneh's photographs is specific, to her country, to her origins, and from this specificity addresses Western appropriation of Dinkenish, and Ethiopian reclaiming of her - not simply her bones, but her story, enigmatic, and in place.

Aida Muluneh is discussed here as exemplary of a feminist aesthetic in photography. Her work takes on an historical discourse - the history of Ethiopia both in itself and in its interactions with the West - and give its deep symbolic form. Her images see through the almost erased perspective of this woman, Dinkenish. The possibility of the feminist force of photographs is always fraught. It necessitates the photographer herself being able to see from a feminist perspective, a task that by no means coheres to or is aligned with simply being a woman. On the contrary, whether the photographer interprets the world around her as one urgently in need of political change is the crux of feminist activism in photography. That said, it is not the photographer's avowed beliefs that shape the image. Rather instead it is the understanding of the political world she inhabits that occurs at a level beneath the threshold of public statement that generates the aesthetic force of feminist intervention in a photographic image. In other words, the photographer herself might or might not publicly avow political activism toward gender equality. What shapes a feminist aesthetic is the risk of form, contour, and symbol, that occurs in the image itself. A photographic image is always political: it emerges from a political space, however private it may seem, and it affects the politics of the world in which it is seen. Most photographs are not consciously intended as political entities but arguably that it always their fate. The circulation of photographs shapes us, forming the cultural imaginary that is the human world. Feminist photography, like that of Aida Muluneh discussed above, responds to this reality of the image-world. It articulates new forms that enter the social field and change the possibility of meaning that attaches to gender and being. 


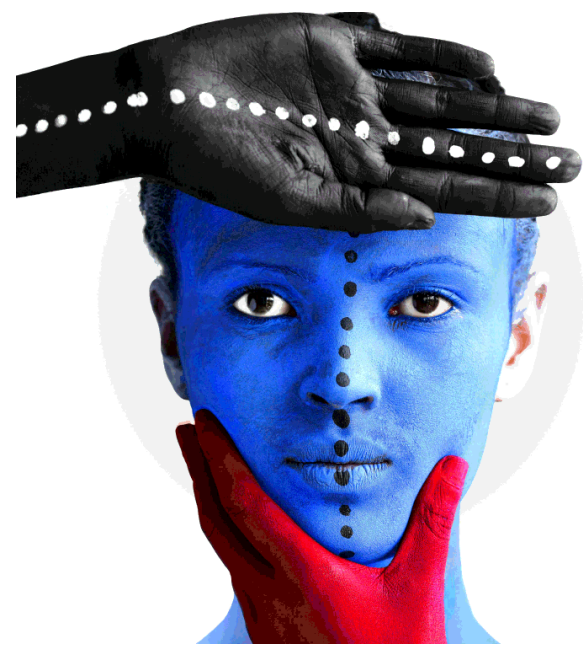

Figure 1: Aida Muluneh, Conquest, Series The Wolf you feed, 2014 Source: https://www.aidamuluneh.com/work/\#/the-wolf-you-feed-1/

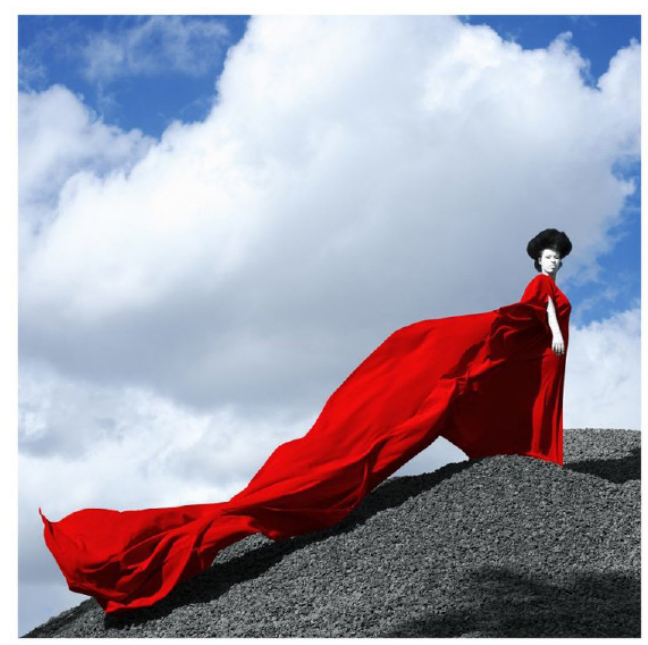

Figure 2: Aida Muluneh, Dinkinesh Part Three, Series The World is 9, 2016 Source: Source: https://www.aidamuluneh.com/work/\#/the-world-is-9-1/

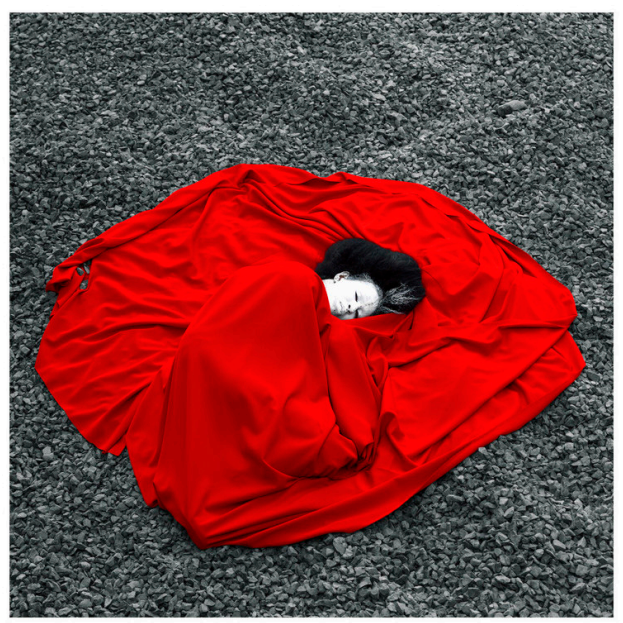

Figure 3: Aida Muluneh, Dinkinesh Part One, Series The World is 9, 2016 Source: https://www.aidamuluneh.com/work/\#/the-world-is-9-9/ 


\section{BIBLIOGRAPHIC REFERENCES}

Arbus, D. (2003). Revelations. New York: Random House.

Barthes, R. (1972). Mythologies. New York: Farrar, Straus \& Giroux.

Barthes, R. (1977). The Death of the Author. In Image, Music, Text (pp. 142-147). New York: Hill and Wang.

Baudrillard, J. (1994). Simulacra and Simulation. Michigan: University of Michigan Press.

Benjamin, W. (1968a). The Work of Art in the Age of Mechanical Reproduction. In H. Arendt (Ed.), Illuminations (pp. 217-252). New York: Harcourt, Brace, Javonich.

Benjamin, W. (1968b). Theses on the Philosophy of History. In H. Arendt (Ed.), Illuminations (pp. 253-264). New York: Harcourt, Brace, Javonich.

Benjamin, W. (1972). A Short History of Photography. Screen, 13(1), 5-26.

Burke, C. (2007). Lee Miller: A Life. Chicago: University of Chicago Press.

Foucault, M. (1994). The Birth of the Clinic. New York: Penguin.

Freeman, B. C. (1997). The Feminine Sublime. Gender and Excess in Women's Fiction. California: University of California Press.

Hand, S. (2011). Facing the Other: the Ethics of Emmanuel Levinas. London: Routledge.

Hillach, A.; Wikoff, J. \& Zimmerman, U. (1979). Walter Benjamin's 'Theories of German Fascism'. New German Critique, 17 [Special Walter Benjamin Issue], 99-119.

Jayawardane, M. N. (2016). Between Nostalgia and Future Dreaming, Transition 120, 116-131.

Kimbel, W. \& Delezene, L. (2009). 'Lucy' Redux: a Review of Research on Australopithecus afarensis. Yearbook of Physical Anthropology 52, 2-48.

Lubow, A. (2016). Diane Arbus: Portrait of a Photographer. New York: Ecco.

Maloof, J. \& Dyer, G. (2011). Vivian Maier: Street Photographer. New York: Powerhouse Books.

Maloof, J. (2014). Vivian Maier: A Photographer Found. New York: Harper.

Muluneh, A. (2009, 22 $2^{\text {nd }}$ July). Ethiopia: Past/Forward Aida Muluneh Book [Post in a blog]. Retrieved from http://muluneh.blogspot.com/2009/07/ethiopia-pastforward-aida-muluneh-book.html.

Rancière, J. (2009). The Emancipated Spectator. London: Verso.

Rancière, J. (2013). Aisthesis. Scenes from the Aesthetic Regime of Art. London: Verso.

Raymond, C. (2016). Francesca Woodman's Dark Gaze: the Diazotypes and Other Late Work. New York: Routledge.

Solnit, R. (2017). The Mother of All Questions. Chicago: Haymarket. 


\section{BIOGRAPHIC NOTE}

Claire Raymond teaches for the program in Art History, and the Department of Sociology, at the University of Virginia. Her books Women Photographers and Feminist Aesthetics, Francesca Woodman and the Kantian Sublime, Witnessing Sadism in Texts of the American South, and the Posthumous Voice in Women's Writing from Mary Shelley to Sylvia Plath, explore topics related to gender, photography, and aesthetic theory. Her PhD in English Literature is from The Graduate School and University Center, City University of New York.

E-mail: scp2u@virginia.edu

University of Virginia, Charlottesville, VA 22904, 434 293-6653, United States of America

* Submitted: $28-07-2016$

* Accepted: 05-08-2017 